\title{
PENINGKATAN HASIL BELAJAR MATEMATIKA BERBAGAI BENTUK PECAHAN MELALUI MAKE A MATCH DI UPT SD NEGERI 12 GRESIK
}

\author{
BUDI RIYANTO \\ UPT SD Negeri 12 Gresik \\ Email : briyanto933@gmail.com
}

\begin{abstract}
ABSTRAK
Penelitian ini bertujuan untuk meningkatkan kemampuan hasil belajar peserta didik kelas IV di UPT SD Negeri 12 Kecamatan Gresik Kabupaten Gresik dalam memahami pembelajaran Matematika pokok bahasan berbagai bentuk pecahan melalui penerapan model pembelajaran Make A Match. Penelitian ini merupakan penelitian tindakan kelas yang terdiri dari dua siklus, setiap siklus terdiri atas perencanaan, pelaksanaan, pengamatan, dan refleksi. Data kemampuan peserta didik dalam memahami berbagai bentuk pecahan dikumpulkan dengan menggunakan lembar observasi. Hasil analisis menunjukkan bahwa penerapan model pembelajaran Make A Match dapat meningkatkan aktivitas dan kemampuan hasil belajar peserta didik kelas IV di UPT SD Negeri 12 Gresik dalam memahami pembelajaran Matematika pokok bahasan berbagai bentuk pecahan melalui penerapan model pembelajaran Make A Match. Secara kuantitatif terjadi peningkatan hasil belajar berbagai bentuk pecahan dari siklus I ketuntasan klasikal sebesar 73\% ke siklus II sebesar $88 \%$. Hasil ini menunjukkan terjadinya peningkatan pemahaman peserta didik terhadap berbagai bentuk pecahan sebesar $15 \%$. Secara kualitatif kemampuan peserta didik dalam memahami berbagai bentuk pecahan meningkat dari kualifikasi sedang ke tinggi. Dengan demikian, penerapan Model Pembelajaran Make A Match dapat meningkatkan hasil belajar berbagai bentuk pecahan pada peserta didik kelas IV UPT SD Negeri 12 Gresik Tahun Pelajaran 2019/2020.
\end{abstract}

Kata Kuci : Model Pembelajaran, Make A Match, Matematika

\section{PENDAHULUAN}

Matematika adalah bidang ilmu yang melatih penalaran supaya berpikir logis dan sistematis dalam menyelesaikan masalah dan membuat keputusan. Mempelajari Matematika memerlukan cara tersendiri karena bersifat khas yaitu abstrak, konsisten, hierarki, dan berfikir deduktif (Herman Hudojo, 1988:3). Sementara itu siswa dalam satu kelas memiliki beragam karakteristik, seperti kemampuan kognitif, kondisi sosial ekonomi, dan minat terhadap Matematika. Dalam mengajar Matematika, pengajar dalam hal ini guru dituntut mamahami karakter setiap siswa sehingga saat mengajar Matematika guru dituntut kreatif dalam menyajikan materi sehingga siswa yang memiliki beragam karakteristik dapat dengan mudah memahami materi pelajaran yang disampaikan.

Menurut Piaget, siswa sekolah dasar masih berada pada masa operasional konkret, yaitu dalam mempelajari materi yang bersifat abstrak harus diawali dengan materi yang konkret. Sedangkan yang terjadi di lapangan masih banyak guru menggunakan model yang bersifat konvensional tanpa memikirkan solusi atau keberhasilan peserta didiknya. Jika hal seperti itu terus dibiarkan tentunya mutu pendidikan akan selalu rendah, dan hal seperti ini pula akan membawakan dampak yang negatif bagi generasi bangsa kita.

Berdasarkan hasil uji kompetensi di kelas IV UPT SD Negeri 12 Gresik pada mata pelajaran Matematika tentang materi berbagai bentuk pecahan mendapatkan beberapa kejanggalan. Model mengajar yang digunakan guru masih bersifat konvensional, sehinga siswa menjadi pasif, membosankan dan mengakibatkan banyaknya nilai siswa yang tidak mencapai KKM yang telah ditentukan 70. Siswa yang mencapai KKM hanya 42\% dari jumlah keseluruhan 33 siswa.

Untuk mengatasi permasalahan dalam proses pembelajaran dan hasil belajar agar lebih baik maka digunakan model pembelajaran Make-A Match sesuai dengan model belajar yang 
dikembangkan oleh Lorna Curran (dalam Rusman 2011). Make-A Match merupakan model pembelajaran aktif, kreatif, efektif, dan menyenangkan (PAKEM), serta pembelajaran kooperatif (Cooperatif Learning) yang mengutamakan kerja sama dan kecepatan di antara siswa untuk mencapai tujuan pembelajaran. Sekiranya dengan pengunaan model pembelajaran Make-A Match ini peserta didik dapat lebih bersemangat dan senang untuk melakukan kegiatan belajar mengajar dan hasil yang di dapat mencapai sesuai dengan KKM yang telah di tentukan.

Hasil belajar adalah penguasaan pengetahuan atau ketrampilan yang dikembangkan oleh mata pelajaran, umumnya ditunjukkan dengan nilai test atau nilai yang diberikan oleh guru (Depdiknas : 2005). Hasil belajar merupakan tingkat perkembangan mental yang lebih baik dengan melakukan usaha secara maksimal yang dilakukan oleh seseorang setelah melakukan usaha-usaha belajar. Hasil belajar biasanya dinyatakan dalam bentuk nilai. Setelah mengkaji pengertian hasil belajar dapat disimpulkan bahwa hasil belajar adalah kemampuan yang dimiliki siswa setelah menerima pengalaman belajarnya. Hasil belajar mempunyai peranan penting dalam proses pembelajaran.

Model pembelajaran menurut Joyce \& Weil adalah suatu rencana atau pola yang dapat digunakan untuk membentuk kurikulum (rencana pembelajaran jangka panjang), merancang bahan-bahan pembelajara, dan membimbing pembelajaran dikelas atau yang lain (Joyce \& Weil, 1980:1). Model pembelajaran Make-A Match (mencari pasangan) merupakan strategi pembelajaran yang dikembangkan oleh Lorna Curran (1994). Sebagaimana model yang lain, model ini merupakan model pembelajaran berkelompok (learning community). Model ini dapat membangkitkan semangat siswa dengan mengikutsertakan peserta didik untuk aktif dalam proses pembelajaran. Pembelajaran kelompok dalam Make-A Match ada dua kelompok yaitu kelompok pemegang masalah dan kelompok pemegang jawaban. Make-A Match dapat dilakukan untuk semua mata pelajaran dan pada semua tingkat pendidikan mulai dari SD sampai SMA. Persiapan awal yang harus dilakukan dalam model pembelajaran ini guru harus memberitahukan apa saja yang harus dipelajari pada pertemuan selanjutnya. Model pembelajaran Make-A Match merupakan strategi yang cukup menyenangkan yang digunakan untuk mengulang materi yang telah diberikan sebelumnya. Namun demikian materi baru pun tetap bisa diajarkan menggunakan model pembelajaran Make-A Match, dengan catatan peserta didik diberi tugas mempelajari topik yang akan diajarkan terlebih dahulu, sehingga ketika masuk kelas mereka sudah memiliki bekal pengetahuan (Hisyam Zain : 2008).

\section{METODE PENELITIAN}

Penelitian ini dilaksanakan di UPT SD Negeri 12 Gresik pada bulan September 2019 Tahun Pelajaran 2019/2020. Subjek penelitian adalah siswa kelas IV dengan jumlah siswa keseluruhan 33 orang, terdiri dari 12 laki-laki dan 21 perempuan. Prosedur penelitian yang digunakan dalam penelitian ini adalah penelitian tindakan kelas. Rancangan yang digunakan adalah model rancangan yang diadaptasi Stephen Kemmis dan Mc. Taggart (1998) dengan menggunakan dua siklus, dengan masing-masing siklus terdiri dari empat tahapan yaitu: (1) perencanaan, (2) tindakan, (3) observasi dan evaluasi, dan (4) refleksi.

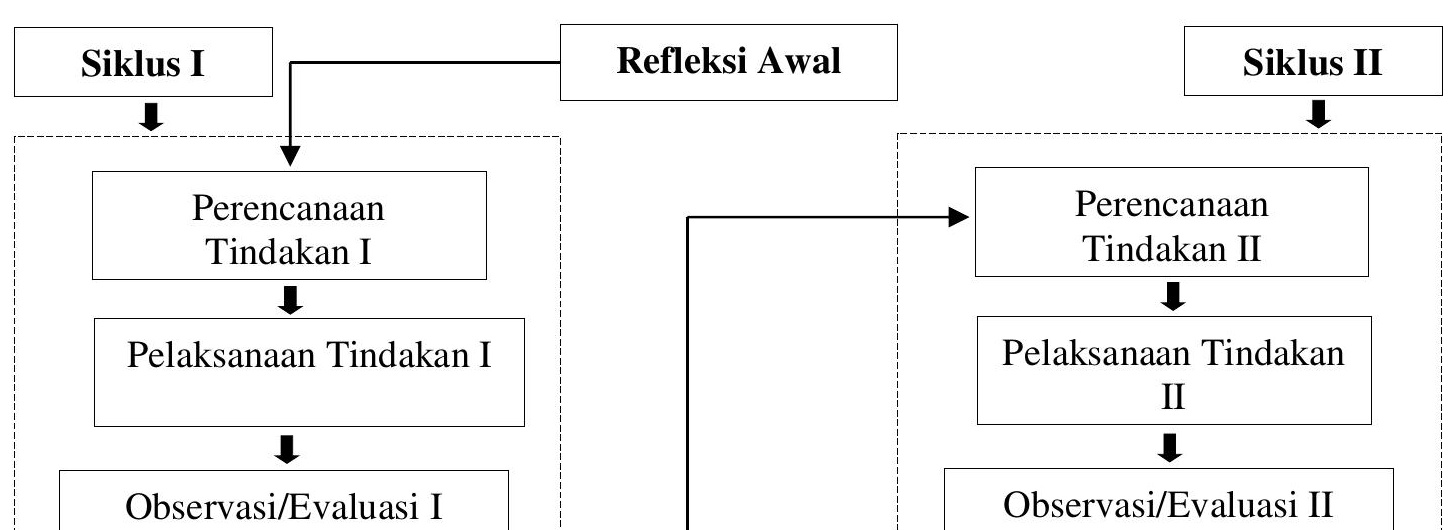




\section{Gambar 1. Rancangan penelitian tindakan kelas}

Data pada penelitian ini berupa data kuantitatif. Data pendukung penelitian dikumpulkan melalui observasi. Observasi ini dilakukan saat kegiatan PBM Matematika berlangsung dengan menggunakan model Make-A Match. Hal yang menjadi perhatian dalam observasi adalah tentang model yang digunakan guru, interaksi guru dan murid, keaktifan siswa, penggunaan media dan keberhasilan PBM dengan menggunakan model Make-A Macth. Pengolahan data dilakukan dengan mentabulasi setiap data sesuai dengan jenis data yang terkumpul. Setelah setiap data diolah dengan teknik tabulasi, kemudian dianalisis untuk mengetahui keberhasilan, kendala, hambatan, dan atau kesulitan yang dihadapi pada setiap pelaksanaan siklus. Analisis data dilakukan bersamaan dengan terkumpulnya setiap data. Hasil analisis kemudian disajikan dalam bentuk deskripsi, tabulasi, grafik, dan teknik-teknik penyajian data bersifat "deskriptif'.

\section{HASIL DAN PEMBAHASAN}

\section{Siklus I}

Dari hasil perbaikan pembelajaran siklus I diperoleh data hasil tes akhir siswa seperti pada tabel berikut :

Tabel 1. Hasil Tes Akhir Perbaikan Pembelajaran Siklus I

\begin{tabular}{ccccc}
\hline Nilai & Frekuensi & $\%$ & Penguasaan Materi & Ketuntasan \\
\hline 100 & 9 & 27 & $>70 \%$ & Tuntas \\
90 & 2 & 6 & & $24(73 \%)$ \\
80 & 2 & 6 & & \\
70 & 11 & 33 & $<70 \%$ & Belum \\
60 & 4 & 12 & & $9(27 \%)$ \\
50 & 5 & 15 & & \\
Jml & 33 & 100 & & \\
Rata-rata Nilai & 73 & & \\
Ketuntasan Belajar & $73 \%(24$ siswa) & & \\
\hline
\end{tabular}

Hasil pembelajaran siklus I belum mencapai kriteria keberhasilan perbaikan yang telah direncanakan. Akan tetapi, jika dibandingkan dengan hasil pembelajaran sebelumnya, hasil perbaikan pembelajaran siklus I menunjukkan kenaikan.

Tabel 2. Hasil Pengamatan Aktivitas Siswa dalam PBM Siklus I

\begin{tabular}{llllll}
\hline No & \multicolumn{1}{c}{ Kegiatan } & \multicolumn{3}{c}{ Skor } \\
& & 1 & 2 & 3 & 4 \\
\hline 1 & Siswa aktif mencari pasangan kartunya? & 1 & 2 & 3 & 4 \\
2 & Siswa mencari pasangan secara tertib? & 1 & 2 & 3 & 4 \\
3 & Siswa mau berdiskusi dengan anggota kelompok? & 1 & 2 & 3 & 4
\end{tabular}


Kelompok siswa berdiskusi secara tertib?

\begin{tabular}{ccc|c}
1 & 2 & 3 & 4 \\
1 & 2 & 3 & 4 \\
1 & 2 & 3 & 4 \\
1 & 2 & 3 & 4 \\
1 & 2 & 3 & 4 \\
1 & 2 & 3 & 4 \\
1 & 2 & 3 & 4 \\
0 & 6 & 0 & 28 \\
\multicolumn{3}{c}{3,4 (baik) }
\end{tabular}

Keterangan

Nilai skor 1 : kurang

Nilai skor 3 : baik

Nilai skor 2 : cukup

Nilai skor 4 : sangat baik

Nilai $=$ Jumlah soal $\mathrm{x}$ perolehan skor $:$ jumlah skor maksimum

Aktivitas siswa belum maksimal, masih ada siswa tidak fokus dalam bekerja sama mencari pasangan kartu, beberapa siswa suka mengganggu temannya dalam, dan siswa merasa batas waktu untuk mencari pasangan kartu terlalu sedikit.

Tabel 3. Hasil Penilaian Kelayakan Media Siklus I

\begin{tabular}{llcc}
\hline No & \multicolumn{1}{c}{ Aspek yang dinilai } & \multicolumn{2}{c}{ Kelayakan } \\
& & Ya & Tidak \\
\hline 1 & Media sesuai dengan tujuan pembelajaran & $\sqrt{ }$ & \\
2 & Media sesuai dengan tingkat kecerdasan siswa & $\sqrt{ }$ \\
3 & Media dapat digunakan acuan pembelajaran & $\sqrt{ }$ & \\
4 & Media mudah penggunaannya dan tidak berbahaya & $\sqrt{ }$ & \\
5 & Siswa mendapat kesempatan menggunakan media & $\sqrt{ }$ \\
6 & Siswa mendapat penjelasan media model Make-A & $\sqrt{ }$ \\
& Match & $67 \%$ & $33 \%$ \\
\hline \multicolumn{5}{c}{ Rata-rata }
\end{tabular}

Berdasarkan data temuan kekurangan dari kegiatan pembelajaran siklus I, maka tindak lanjut yang perlu dilakukan dalam tindakan 2 yaitu menjelaskan penggunaan model Make-A Match dengan lebih rinci sehingga siswa betul-betul paham. Memantau siswa secara intensif agar fokus, tidak menganggu teman yang lain, serta dapat memberikan bimbingan kepada siswa yang kesulitan secara individu.

\section{Siklus II}

Pelaksanaan pembelajaran siklus II mengacu pada revisi pembelajaran siklus I. Hasil pengamatan adalah sebagai berikut :

Tabel 4. Hasil Tes Akhir Perbaikan Pembelajaran Siklus II

\begin{tabular}{ccccc}
\hline Nilai & Frekuensi & $\%$ & Penguasaan Materi & Ketuntasan \\
\hline 100 & 18 & 55 & $>70 \%$ & Tuntas \\
90 & 2 & 6 & & $29(88 \%)$ \\
80 & 5 & 15 & & \\
70 & 4 & 12 & & \\
60 & 4 & 12 & $<70 \%$ & Belum \\
\hline
\end{tabular}


$\begin{array}{lll}50 & 0 & 0\end{array}$

Jml $\quad 33 \quad 100$

$4(12 \%)$

Rata-rata Nilai $\quad 88$

Ketuntasan Belajar $88 \%$ (29 siswa)

Penggunaan model Make-A Match dalam pembelajaran siklus II sudah membantu siswa meningkatkan ketuntasan belajar dan penguasaan materi.

Tabel 5. Hasil Pengamatan Aktivitas Siswa dalam PBM Siklus II

\begin{tabular}{|c|c|c|c|c|c|}
\hline \multirow[t]{2}{*}{ No } & \multirow[t]{2}{*}{ Kegiatan } & \multicolumn{4}{|c|}{ Skor } \\
\hline & & 1 & 2 & 3 & 4 \\
\hline 1 & Siswa aktif mencari pasangan kartunya? & 1 & 2 & 3 & 4 \\
\hline 2 & Siswa mencari pasangan secara tertib? & 1 & 2 & 3 & 4 \\
\hline 3 & Siswa mau berdiskusi dengan anggota kelompok? & 1 & 2 & 3 & 4 \\
\hline 4 & Kelompok siswa berdiskusi secara tertib? & 1 & 2 & 3 & 4 \\
\hline 5 & Siswa yang dapat mencocokan kartu diberi poin? & 1 & 2 & 3 & 4 \\
\hline 6 & Siswa merasa bosan mengikuti PBM? & 1 & 2 & 3 & 4 \\
\hline 7 & Siswa senang mengikuti PBM? & 1 & 2 & 3 & 4 \\
\hline 8 & Ada siswa yang kesulitan terhadap materi? & 1 & 2 & 3 & 4 \\
\hline 9 & Media dapat digunakan siswa dengan baik? & 1 & 2 & 3 & 4 \\
\hline \multirow[t]{3}{*}{10} & Siswa tidak dapat menggunakan media peraga? & 1 & 2 & 3 & 4 \\
\hline & Perolehan Skor & 0 & 0 & 3 & 36 \\
\hline & & \multicolumn{4}{|c|}{ 3,9 (amat baik) } \\
\hline \multicolumn{6}{|c|}{ Keterangan } \\
\hline \multicolumn{6}{|c|}{ Nilai skor 1 : kurang } \\
\hline \multicolumn{6}{|c|}{ Nilai skor 2 : cukup } \\
\hline \multicolumn{6}{|c|}{ Nilai $=$ Jumlah soal $\mathrm{x}$ perolehan skor $:$ jumlah skor maksimum } \\
\hline
\end{tabular}

Berdasarkan data temuan hasil observasi, terlihat aktivitas siswa sudah kelihatan sangat baik, siswa sudah bisa bekerja sama dalam kelompok, sehingga siswa aktif dan kreatifitasnya berkembang sehingga bisa menyalurkan pendapatnya dalam menyelesaikan tugas kelompok. 
Vol 1. No. 3, Juli 2021 P-ISSN : 2774-8014, e-ISSN : 2774-7034

Tabel 6. Hasil Penilaian Kelayakan Media Siklus II

\begin{tabular}{|c|c|c|c|}
\hline \multirow[t]{2}{*}{ No } & \multirow[t]{2}{*}{ Aspek yang dinilai } & \multicolumn{2}{|c|}{ Kelayakan } \\
\hline & & Ya & Tidak \\
\hline 1 & Media sesuai dengan tujuan pembelajaran & $\sqrt{ }$ & \\
\hline 2 & Media sesuai dengan tingkat kecerdasan siswa & $\sqrt{ }$ & \\
\hline 3 & Media dapat digunakan acuan pembelajaran & $\sqrt{ }$ & \\
\hline 4 & Media mudah penggunaannya dan tidak berbahaya & $\sqrt{ }$ & \\
\hline 5 & Siswa mendapat kesempatan menggunakan media & $\sqrt{ }$ & \\
\hline 6 & Siswa mendapat penjelasan media model Make-A Match & $\sqrt{ }$ & \\
\hline & Rata-rata & $100 \%$ & $0 \%$ \\
\hline
\end{tabular}

Media Make-A Match yang digunakan dalam pembelajaran siklus II sudah layak/optimal (100 \%). Pelaksanakan proses pembelajaran telah dilakukan dengan semaksimal mungkin, perolehan hasil proses belajar telah dapat dikuasai dengan baik oleh siswa.

Hasil kemampuan memahami berbagai bentuk pecahan merupakan tes kognitif yang mengharuskan siswa untuk betul-betul dapat memahami apa yang sudah dipelajari. Nilai ketuntasan klasikal sebesar $73 \%$, menunjukkan bahwa siswa telah menguasai materi yang diajarkan walaupun belum begitu sempurna. Hasil ini belum menunjukkan peningkatan kemampuan siswa menguasai mata pelajaran Matematika pokok bahasan berbagai bentuk pecahan apabila dibandingkan dengan nilai awal siswa sesuai data yang sudah disampaikan dalam analisis sebelumnya.

Pelaksanaan penerapan model pembelajaran Make A Match di siklus I telah memberikan bukti bahwa penggunaan metode tertentu akan berpengaruh terhadap hasil belajar siswa. Hal ini sesuai dengan hasil meta analisis metode pembelajaran yang dilakukan oleh Soedomo,1990 (dalam Puger, 2004) yang menyatakan bahwa metode pembelajaran yang diterapkan oleh seorang guru berpengaruh terhadap hasil belajarnya.

Hasil belajar yang diperoleh dari kemampuan memahami berbagai bentuk pecahan di siklus II menunjukkan bahwa kemampuan siswa dalam mengikuti pelajaran sudah cukup baik. Ini terbukti dari rata-rata nilai siswa mencapai 88 dengan ketuntasan klasikal $88 \%$. Hasil ini menunjukkan bahwa model pembelajaran Make A Match telah berhasil meningkatkan kemampuan siswa menempa ilmu sesuai harapan. Model pembelajaran Make-A Match merupakan strategi yang cukup menyenangkan yang digunakan untuk mengulang materi yang telah diberikan sebelumnya. Namun demikian materi baru pun tetap bisa diajarkan menggunakan model pembelajaran Make-A Match, dengan catatan peserta didik diberi tugas mempelajari topik yang akan diajarkan terlebih dahulu, sehingga ketika masuk kelas mereka sudah memiliki bekal pengetahuan (Hisyam Zain, 2008).

Dari hasil penelitian menunjukkan adanya peningkatan hasil nilai pra siklus, nilai siklus I dan siklus II. Pra siklus yang hanya mencapai nilai rata-rata 48 naik di siklus I menjadi 73 dan siklus II naik menjadi 88. Ketuntasan klasikal juga mengalami kenaikan, dari pra siklus $42 \%$ menjadi $73 \%$ di siklus I dan naik menjadi $88 \%$ di siklus II. Hal ini sejalan pula dengan temuan-temuan peneliti lain seperti yang dilakukan oleh Inten (2004) dan Puger (2004) yang pada dasarnya menyatakan bahwa metode pembelajaran yang diterapkan berpengaruh terhadap hasil belajar siswa.

Pelaksanakan proses pembelajaran telah dilakukan dengan semaksimal mungkin, perolehan hasil proses belajar telah dapat dikuasai dengan baik oleh siswa. Hampir semua siswa dapat menguasai konsep yang diajarkan, antusias, keaktifan, persiapan dalam mengikuti pembelajaran semakin meningkat, meskipun dalam pembelajaran juga masih ditemukan beberapa siswa yang tetap canggung ketika mengikuti proses belajar mengajar dalam jumlahnya juga semakin berkurang. 
Hasil pengamatan sikap siswa, terlihat adanya peningkatan, yaitu siswa menjadi lebih aktif bekerja dengan kelompoknya, berani bertanya, dan siswa merasa senang, dengan model belajar yang digunakan. Tampak bahwa siswa tidak bosan selama mengikuti kegiatan pembelajaran, dan hasil belajar Matematika tentang berbagai bentuk pecahan juga menjadi meningkat. Dengan demikian dapat dikatakan penerapan model pembelajaran Make-A Match dapat meningkatkan hasil belajar berbagai bentuk pecahan. Pembelajaran model pembelajaran Make-A Match sangat membantu guru meningkatkan kualitas pembelajaran di kelas terutama dalam mengajarkan materi berbagai bentuk pecahan maupun materi lainnya.

\section{KESIMPULAN}

Berdasarkan hasil penelitian dan pembahasan, maka dapat dikemukakan bahwa setelah dilakukan tindakan dengan menggunakan model pembelajaran Make-A Match pada peserta didik kelas IV UPT SD Negeri 12 Gresik semester I tahun pelajaran 2019/2020 terjadi perubahan penguasaan berbagai bentuk pecahan. Perubahan ini nampak pada hasil observasi maupun pos test yang didapat dari pra siklus, tindakan siklus I, dan tindakan siklus II. Data perkembangan peningkatan hasil belajar peserta didik dapat dilihat dari prosentasi ketuntasan belajar peserta didik, yaitu dari pra siklus $42 \%$ naik menjadi $73 \%$ pada siklus I dan $88 \%$ pada siklus II. Dengan hasil penelitian ini, penulis menyarankan kiranya rekan-rekan guru yang lain dapat mencoba menerapkan model pembelajaran Make-A Match pada mata pelajaran Matematika ataupun mata pelajaran lainnya.

\section{DAFTAR PUSTAKA}

Ahmadi. (2010). Proses Pembelajaran Kreatif dan Inovatif dalam kelas. Jakarta: Prestasi Pustaka. Arikunto, Suharsimi; Suhardjono; Supardi. (2006). Penelitian Tindakan Kelas. Jakarta: PT Bumi Aksara.

Badan Standar Nasional Pendidikan. (2007). Peraturan Menteri Pendidikan Nasional Republik Indonesia Nomor 41 Tahun 2007.Jakarta: BSNP.

Depdiknas. (2006).Pedoman Penilaian Hasil Belajar SD. Jakarta.

M.Heruman. (2007). Model Pembelajaran Matematika Di Sekolah Dasar. Bandung: ROSDA.

Nana Sudjana. (1989). Cara Belajar Siswa Aktif dalam Proses Belajar Mengajar. Bandung: Sinar Baru.

Puger, I Gusti Ngurah. (2004). Belajar Kooperatif. Diktat Perkuliahan Mahasiswa Unipas.

Rusman. (2011). Model -Model Pembelajaran. Jakarta : Rajawali Pers.

Slameto. (2010). Belajar \& Faktor-Faktor yang Mempengaruhinya. Jakarta: Rineka Cipta.

Suhasini, Arikunto., Suhardjono., Supardi. (2006). Penelitian Tindakan Kelas. Jakarta: Bumi Aksara. 